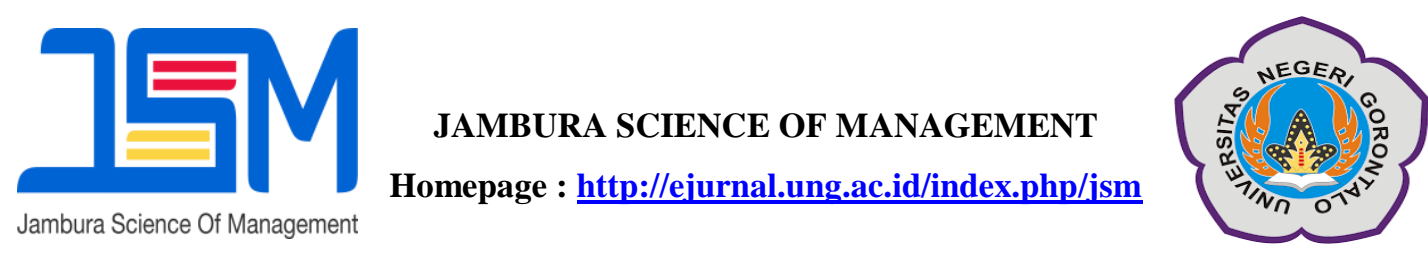

\title{
The Effect Of Green Marketing Concept On Consumer Intention To Buy Savana Project Product
}

\author{
Rizky Faizal $A^{1}$, Ike Ratnasari ${ }^{2}$ \\ ${ }^{1,2}$ Department of Management, Sekolah Tinggi Ilmu Ekonomi Kertanegara Malang, \\ Indonesia \\ E-Mail: rizkyfaizalalamin@gmail.com
}

\begin{abstract}
:
This study aims to determine and analyze the influence part of the green marketing concept where the variables studied include green product, green promotion, green packaging. Towards Savana Project product buying intention, and to know and analyze which variables have the dominant influence on consumer buying interest. The population of this study is all prospective buyers of Savana Project products using the Non-Probability Sampling Method, namely convenience sampling where members of the population can be easily selected as samples. The number of samples in this study were 121 respondents. The analysis technique used is multiple linear regression analysis. Based on the results of the analysis show that all variables simultaneously have a significant effect on buying intention, and are able to contribute to customer loyalty variables by $58.8 \%$. Partially only green products that do not have a significant influence on buying interest. While the other two, namely green promotion and green packaging have a significant influence on consumer buying interest. green promotion becomes the dominant influence variable on customer loyalty with a regression coefficient of 0.501 greater than the other three variables. This shows that green promotion is a variable that greatly influences consumer buying interest.
\end{abstract}

\section{Keywords: Green product; Green promotion; Green packaging; Intention}

Environmental problems as a result of human activities, both directly and indirectly have become international issues since the last 40 years. Various parts of the world have tried to reduce various activities that can exacerbate environmental damage. The views and patterns of human life began to shift along with increasing awareness and awareness of the environment. This is evidenced by the existence of a social movement with the issue of saving the environment. This is also a demand for business people to carry out environmental responsibility so that a pattern of business activity approaches based on environmental sustainability arises.

The issue of global warming also reinforces the notion that all world population should understand the importance of awareness of the environment. The emergence of an awareness of environmental issues has triggered the industrial world to present a 
new concept of marketing that emphasizes environmental issues. Increasing the market that cares about the environment is the impact of increasing business attention to widespread environmental issues (Laroche et al., 2001). Even today, business people are starting to implement international standards, better known as ISO-14000 regarding environmental management. Companies that initially did not use environmentally friendly strategies are now starting to implement environmentally friendly strategies called green marketing strategies. Green marketing strategy is defined as all activities designed to produce and facilitate each exchange to fulfill human needs or desires, so that satisfaction with needs and desires occurs, with minimal impact on environmental losses (Polonsky in Sarkar, 2012: 121). Some companies in the world can accept green marketing widely as one of the appropriate strategies to develop.

Some companies are committed to green marketing in marketing communications, the goal is to gain market share from consumers who care about the environment. People who are aware and more concerned with the environment will have a big influence on purchasing decisions because they will continue to buy environmentally friendly products even though the price of environmentally friendly products is more expensive than ordinary products. Consumers also consider the environmentally friendly products that they will consume based on the price offered and the expected quality. Satisfied consumers will repeat the purchase which will eventually become a company customer. Loyal customers can generate large revenues for years, if the company has customers who are loyal to environmentally friendly products, the company benefits both the company and the environment.

By considering the green marketing strategy, it is expected to influence consumer purchasing decisions. Purchasing decisions made by customers involve customer confidence in a product, resulting in confidence in the truth of the actions taken. The customer's confidence in the purchase decision he presents the extent to which the customer has confidence in his decision to choose a product. In consumer behavior, many factors influence consumer buying decisions. These factors are prices, brands, attributes, promotions and so on. Factors that influence the decision to buy consumers for a product can come from within the consumer and come from outside the consumer (Kusumastuti, 2011: 2).

Green marketing is one of the things that can influence emotional feelings and consumer plans so that it has an impact on buying interest. Go green products emerge intending to convey that when consumers consume them there will be more value; there will be benefits besides being satisfied also consumers have taken care of the environment. Savana Projects, a business developed by a nature activist who puts forward issues about the environment in each of its products. T-shirts, stainless straws, zines, posters, stickers are products from Savana Projects, besides that, they also offer rental outdoor tools. in each production, they always provide environmental issues in marketing. In zines, the posters and stickers they produce are always filled with voices to love the environment and also care for the green space. For their own shirts, they use a system with the purchase 
of a shirt, so consumers help plant one plant.

Green Marketing or can also be called green marketing is the development of a marketing process/activity that uses environmental issues as a strategy to market products or services. This is in accordance with the statement of Kotler and Keller (2006) "Green Marketing as the movement which is dire".

\section{METHOD}

The research method used by the authors in this study is the descriptive method. According to M. Hariwijaya M. Djaelani (2004) descriptive research is: "Research that aims to examine and determine as much information as possible from a phenomenon. The quantitative approach is a decision model that uses numbers. In theory, quantitative researchers set aside and determine variable changes and categories of variables. All of these variables are bound in a hypothetical frame that often comes before data in a quantitative approach, in the case of observations made through a narrow lens on a series of variables that have been previously designed.

The scope of this research is the relationship between Green Marketing and Purchasing Decisions. Green Marketing options as one of the research variables given the importance of concern for an increasingly damaged environment, the arrival of green marketing will be one of the troubleshooting of environmental problems. Consumers will consider a purchasing decision with additional consideration of environmental issues.

This research was conducted at the Savana Projects workshop in Baran Subdistrict, Gempol Pasuruan. With the time determined based on research needs carried out in November 2018 to February 2019.

The instrument in this study was a questionnaire assisted with e-form. with an infinite number of population, in this study using Non-Probability Sampling, namely the sampling method taken based on the availability of elements and ease of obtaining it (Cooper, 1997). And researchers got 121 respondents in this study.

The scale of the research used is to describe all three independent variables, namely green product as $\mathrm{X} 1$, green promotion as $\mathrm{X} 2$, and green packaging as $\mathrm{X} 3$. and the dependent variable (Y) is measured by a Likert scale which has weights from 1 to 5 , with alternative answers for each instrument to have gradations from very negative to very positive.

By using statistical methods to analyze the relationship between variables, namely by multiple linear regression analysis. Analysis with multiple linear regression methods is used through a distributed questionnaire to get the value of the marketing mix variable. This multiple linear analysis is used to see whether the influence of the variables tested is strong or not, the effect of the marketing mix variable on customer loyalty. Multiple linear regression analysis was carried out using a "Statistical Package for Social Science" analysis tool (SPSS for Windows) which was operated computer call. Both in the manual calculation and using computer aids in this study the authors used the SPSS program to look for regression coefficients. In general, the $\mathrm{Y}$ observation data is influenced by independent variables $\mathrm{X} 1$, $\mathrm{X} 2, \mathrm{X} 3, \ldots . . \mathrm{Xn}$, so the general formula of 
this multiple linear regression is as follows:

The formula for multiple linear regression is (Husein Umar, 2001, p. 127):

$$
\mathrm{Y}=\mathrm{a}+\mathrm{b} 1 \mathrm{X} 1+\mathrm{b} 2 \mathrm{X} 2+\mathrm{b} 3 \mathrm{X} 3+\mathrm{e}
$$

Where :

$\mathrm{X} 1=$ Variable green product

$\mathrm{X} 2=$ Variable green promotion

$\mathrm{X} 3=$ Green packaging variable

$\mathrm{Y}=$ Consumer loyalty

The respondents of this study consisted of all prospective buyers of Savana Projects products who had bought or who had never purchased Savana Projects products. The number of population is unlimited, the sample is determined by convenience sampling where members of the population can be easily selected as samples. Following are the data details, the researcher obtained data from the Questionnaire

Reliability Statistics

\begin{tabular}{|c|c|c|}
\hline $\begin{array}{c}\text { Cronbach's } \\
\text { Alpha }\end{array}$ & $\begin{array}{c}\text { Cronbach's } \\
\text { Alpha Based } \\
\text { on } \\
\text { Standardized } \\
\text { Items } \\
\end{array}$ & $\mathrm{N}$ of Items \\
\hline .934 & .934 & 19 \\
\hline
\end{tabular}

Source: Primary Data Processed (2018)

The questionnaire distributed to respondents was 50 questionnaires. Based on the above details, 35 questionnaires have returned and 15 questionnaires have not returned. The questionnaire that filled out did not meet the requirements of 6 questionnaires. researchers used a google $\mathrm{a}=$ Constant

b1 = Standard regression coefficient of Variable green products

b2 = Standard regression coefficient of Variable green promotion

b3 = Standard regression coefficient from Variable green packaging $\mathrm{e}=$ Disturbance

\section{RESULTS AND DISCUSSION}

form to reach consumers whose location was far from the reach of researchers and questionnaires filled in in the google form as many as 92 questionnaires. So the researcher got 121 questionnaires that could be processed.

This type of research is quantitative research. This study examines the effect of green marketing concepts (green products, green promotion, green packaging) on consumer buying interest in Savana Projects, therefore using multiple linear regression analysis techniques with the help of SPSS software.

Test Validity Table

From the table above, it can be seen that all the calculated $r$ values are greater than the $r$ table. Then it can be concluded that all green product instruments, green promotion, green packaging, and buying interest are valid.

In this study the measurement of the reliability of the questionnaire through the Cronbach Alpha $(\alpha)$ statistical test with the SPSS for windows program. According to Nunnally (in Imam Ghozali, 2006)) a construct or variable can be said to be reliable if it gives a Cronbach Alpha value $>0.60$ in the results 
Testing is done using SPSS version 23 for Windows with the following criteria:

From the table above it can be seen that the alpha $\mathrm{r}$ value is 0.934 which is> 0.9 which means that it has high reliability so that it can be used as a research instrument, to prove the hypothesis about the influence of the variables of green marketing dimensions partially or jointly on consumer buying interest. The statistical calculation in multiple linear regression analysis used in this study was to use the SPSS computer program assistance for Statistical Version 23.

The equation formed is as follows:

$\mathrm{Y}=0.864+0.122 \mathrm{X} 1+0.501 \mathrm{X} 2+$ $0.226 \mathrm{X} 3+0.258$

Based on the results of the equation, it can be explained as follows:

a) Constant (a) $=0.864$ shows the amount of buying interest if there is no green product $(\mathrm{X} 1)$, green promotion (X2), green packaging (X3), then the amount of consumer buying interest $(\mathrm{Y})$ is 0.864 .

b) Green product regression coefficient (X1) of 0.122 indicates the magnitude of the effect of $\mathrm{X} 1$ variable on buying interest (Y), regression coefficient marked positive indicates that green product (X1) has a direct effect on consumer buying interest, which means that green products will cause increased buying interest consumers.

c) Green promotion regression coefficient (X2), amounting to 0.501 shows the magnitude of the effect of $\mathrm{X} 2$ variable on buying interest (Y), the regression coefficient marked positive indicates that green promotion (X2) has a direct effect on consumer buying interest, which means that the better price will cause increased buying interest.

d) Green packaging regression coefficient (X3) of 0.226 shows the magnitude of the effect of $\mathrm{X} 3$ variables on consumer buying interest (Y), regression coefficients with positive signs indicate that green packaging (X3) has a direct effect on

\begin{tabular}{ccccc}
\hline Variable & $\begin{array}{c}\text { Indicat } \\
\text { or }\end{array}$ & $\begin{array}{c}\mathbf{r} \\
\text { count }\end{array}$ & $>$ & $\begin{array}{c}\mathbf{r} \\
\text { table }\end{array}$ \\
\hline \multirow{2}{*}{ Green } & $\mathrm{X} 1,1$ & 0.578 & $>$ & 0.1786 \\
Product & $\mathrm{X} 1,2$ & 0.693 & $>$ & 0.1786 \\
& $\mathrm{X} 1,3$ & 0.519 & $>$ & 0.1786 \\
& $\mathrm{X} 2,1$ & 0.673 & $>$ & 0.1786 \\
& $\mathrm{X} 2,2$ & 0.641 & $>$ & 0.1786 \\
Green & $\mathrm{X} 2,3$ & 0.577 & $>$ & 0.1786 \\
Promotion & $\mathrm{X} 2,4$ & 0.706 & $>$ & 0.1786 \\
& $\mathrm{X} 2,5$ & 0.744 & $>$ & 0.1786 \\
& $\mathrm{X} 2,6$ & 0.704 & $>$ & 0.1786 \\
Green & $\mathrm{X} 3,1$ & 0.653 & $>$ & 0.1786 \\
Packaging & $\mathrm{X} 3,2$ & 0.619 & $>$ & 0.1786 \\
& $\mathrm{X} 3,3$ & 0.681 & $>$ & 0.1786 \\
& $\mathrm{X} 3,4$ & 0.585 & $>$ & 0.1786 \\
& $\mathrm{Y}, 1$ & 0.572 & $>$ & 0.1786 \\
& $\mathrm{Y}, 2$ & 0.656 & $>$ & 0.1786 \\
Intention & $\mathrm{Y}, 3$ & 0.635 & $>$ & 0.1786 \\
& $\mathrm{Y}, 4$ & 0.67 & $>$ & 0.1786 \\
& $\mathrm{Y}, 5$ & 0.616 & $>0.1786$ \\
& $\mathrm{Y}, 6$ & 0.477 & $>$ & 0.1786 \\
\hline
\end{tabular}

consumer buying interest, which means better promotion will cause an increase consumer buying interest.

Model Summary

\begin{tabular}{|l|l|r|r|}
\hline Model & $\mathrm{R}$ & \multicolumn{1}{c|}{$\mathrm{R}$} & Adjusted \\
Square & R Square \\
\hline 1 & $.773^{\mathrm{a}}$ & .598 & .588 \\
\hline
\end{tabular}

a. Predictors: (Constant), Rx3, Rx1, Rx2

b. Dependent Variable: Intention

Source: Primary Data Processed (2018)

From the table above it can be seen that the adjusted R2 value is 0.588 or $58.8 \%$. This figure shows that all green product variables (X1), green promotion 
(X2), green packaging (X3) contribute to consumer buying interest "Savana Project" of $58.8 \%$ while the remaining $41.2 \%$ is influenced by other variables outside of the independent this research.

The normality test is used to test whether the data used is normally distributed or not. Testing is done by using a normal probability plot curve, provided that the points on the graph spread and coincide with a diagonal graph then the data used is normally distributed (Ghozali, 2005: 83). The results of graph testing can be seen in the following picture:

Normal P.P Plot of Regression Standardized Residual

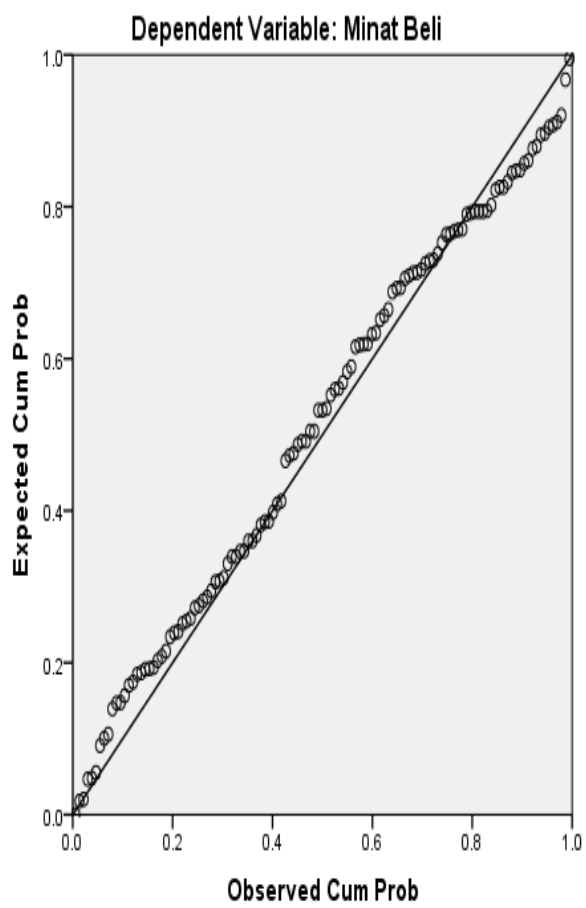

Source: Primary Data Processed (2018)

it can be seen that the points on the graph spread and coincide to follow around the diagonal graph and follow the direction of the diagonal line, thus the data is normally distributed.

Multicollinearity test aims to test whether the regression model found a correlation between independent variables.
A good regression model should not correlate with independent variables (Ghozali, 2011: 106). A regression model that is free from multicollinearity is a model that has a tolerance value of 10.01 or if the value of the variance inflation factor $(\mathrm{VIF}) \leq 10$.

Based on variant inflation factors (variance inflation factor) or VIF obtained through the calculation of SPSS the data above shows that between independent variables namely Green product, Green Promotion, Green Packaging does not occur multicollinearity, because the tolerance value of each independent variable is above 0.1 and the VIF value of each independent variable is below 10 (Ghozali, 2005: 98).

Heteroscedasticity test aims to test whether in the regression model variance from residual inequality occurs one observation to another observation (Ghozali, 2016: 134). The method used to determine the presence or absence of heteroscedasticity in this study is by looking at the image pattern / Scatterplots. if the graph forms a special pattern then the model has heteroskedastistas. However, if there is no clear pattern, and the points spread above and below number 0 on the $\mathrm{Y}$ axis, heteroskedastistas do not occur (Ghozali, 2005: 115). From the results of the study, it can be seen that the distribution of data is above and below the zero on the $\mathrm{Y}$-axis and it appears that the data follows the direction of the regression line, not forming a certain pattern that is regular so that heteroskedastistas do not occur.

Analysis of multiple linear regression is used in this study with the aim of proving the hypothesis about the influence of the variables of green marketing dimensions partially or jointly 
on consumer buying interest. The statistical calculation in multiple linear regression analysis used in this study was to use the SPSS.

it is known that multiple linear regression models to determine the effect of independent variables on the dependent variable. The equation formed is as follows:

$\mathrm{Y}=0.864+0.122 \mathrm{X} 1+0.501 \mathrm{X} 2+$ $0.226 \mathrm{X} 3+0.258$

Based on the results of the equation, it can be explained as follows:

a) Constant (a) $=0.864$ shows the amount of buying interest if there is no green product (X1), green promotion (X2), green packaging (X3), then the amount of consumer buying interest $(\mathrm{Y})$ is 0.864 .

b) Green product regression coefficient (X1) of 0.122 indicates the magnitude of the effect of $\mathrm{X} 1$ variable on buying interest $(Y)$, regression coefficient marked positive indicates that green product (X1) has a direct effect on consumer buying interest, which means that green products will cause increased buying interest consumers.

c) Green promotion regression coefficient (X2), amounting to 0.501 shows the magnitude of the effect of $\mathrm{X} 2$ variable on buying interest (Y), the regression coefficient marked positive indicates that green promotion (X2) has a direct effect on consumer buying interest, which means that the better price will cause increased buying interest.

d) Green packaging regression coefficient (X3) of 0.226 shows the magnitude of the effect of $\mathrm{X} 3$ variables on consumer buying interest $(\mathrm{Y})$, regression coefficients with positive signs indicate that green packaging (X3) has a direct effect on consumer buying interest, which means better promotion will cause an increase consumer buying interest.
F Test

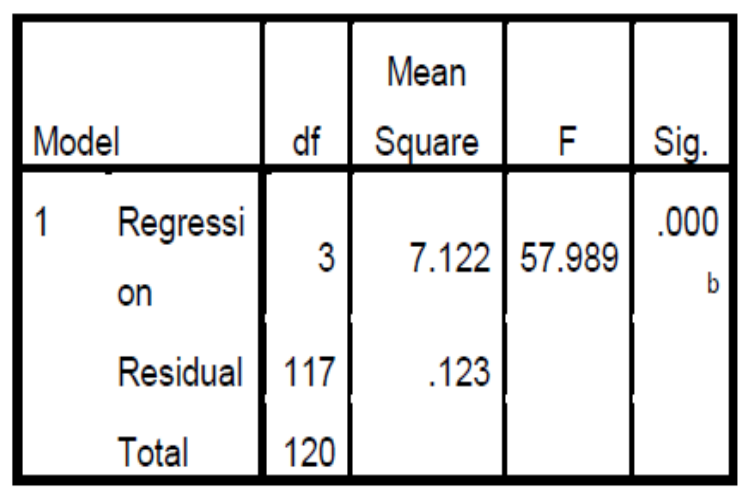

Source: Primary Data Processed (2018)

Based on table, the results of the calculated $F$ test show the value of $F$ count $=57,989$. this can indicate that the value of $F$ count> $\mathrm{F}$ table is $57,989>2.682$ so the hypothesis $\mathrm{H} 0$ is rejected and $\mathrm{H} 4$ is accepted because $\mathrm{F}$ count is greater than $\mathrm{F}$ table in CI $($ Confidence Interval $)=95 \%$. This means that together with the independent variable green product (X1), green promotion (X2), green packaging (X3). Interest in buying as a dependent variable.

Based on the table above it can be concluded that

1. Effect of Green Product on buying interest

Based on the table, the value of $t$ count is 1.428 , with a Sig value of 0.156 . This shows that the calculated $t$ value is smaller than table 1,980, and the Sig value is greater than 0.05 . Thus H0 is accepted while $\mathrm{H} 1$ is rejected. Meaning that the green product does not have a significant effect on consumers' Savanna Project buying interest.

2. Effect of Green Promotion on buying interest

Based on the table, the value of t count is 5.388, with a Sig value of 0.00 . This shows that the calculated $\mathrm{t}$ value is greater than $\mathrm{t}$ table 1,980 and the Sig value is smaller than 0.05 . Thus $\mathrm{H} 0$ is 
rejected while $\mathrm{H} 2$ is accepted. it means that green promotion has a significant influence on consumers' interest in buying Savana Project.

3. Effect of Green Packaging on buying interest

Based on the table the value of $t$ count is 2.570 with a Sig value of 0.01 . This shows that the calculated $t$ value is greater than t table 1,980 and the Sig value is smaller than 0.05 . Thus $\mathrm{H} 0$ is rejected while $\mathrm{H} 3$ is accepted. it means that green promotion has a significant influence on consumers' interest in buying Savana Project.

\section{Discussion}

Discussion of the results of the hypothesis statistical test

1. Simultaneously

$\mathrm{H} 0$ is rejected, and $\mathrm{H} 4$ is accepted because $\mathrm{F}$ count is greater than $\mathrm{F}$ table in CI (Confidence Interval) $=95 \%$. This means that together with the independent variable green product (X1), green promotion (X2), green packaging (X3). Interest in buying as a dependent variable. This is in line with the results of Fatur Rahman, Pamasang S. Siburian, Gusti Noorlitaria (2017).

2. Partially

$\mathrm{H} 1$ is rejected and $\mathrm{H} 0$ is accepted where the green product variable does not have a significant effect on Savana Project consumer buying interest. This is because some respondents are still a little layman with the green concept of the product. And still, tend to consume ordinary products.

$\mathrm{H} 2$ was added where the variable green promotion had a significant effect on consumer buying interest in Savana Project by Friska's research
(2014). Especially for consumers who care about the environment. Savana Project promo method is very positive by inviting natural activists to act as well as the theme of one product as well as donating a tree is a breakthrough that greatly influences consumer buying interest.

$\mathrm{H} 3$ is accepted where the green packaging variable has a significant effect on Savana Project consumer buying interest, this is in accordance with Ratnawati's research (2015). Respondents care about the environment. Savana Project tries to minimize waste through the way they use packaging. A simple way to encourage consumers to protect the environment and also influence consumer buying interest.

In this study, the variable green promotion is the most dominant variable towards consumer buying interest.

Based on the test of the coefficient of determination, it can be seen that the adjusted R2 value is 0.588 or $58.8 \%$. This figure shows that all green product variables (X1), green promotion (X2), green packaging (X3) contribute to consumer buying interest "Savana Project" of $58.8 \%$ while the remaining $41.2 \%$ is influenced by other variables outside of the independent this research. These contributions provide information to Savana Project owners in their efforts to develop their businesses and increase customer loyalty, so that they pay more attention to products, prices, promotions, and locations. While $41.2 \%$ of the other factors need to be pursued further so as not to be a stumbling block for business development to be carried out. In the future, Savana Project must continue to 
develop a green marketing strategy and can see what consumers are interested in.

\section{Limitations of Research}

In this study researchers experienced several limitations that could affect the conditions of the results of the research conducted. The limitations include:

1. Time management is less good than researchers who are also workers.

2. Respondents who are still unfamiliar with green marketing.

3. There are still answers that are not consistent according to the observations of the researchers. Some respondents are not thorough.

4. This study is too focused on the relationship in a partial variable

\section{CONCLUSION}

Based on research from the influence of green product, green promotion, green packaging on consumer buying interest in Savana Project. So the researcher can conclude several things as follows:

Based on the test of the coefficient of determination the adjusted R2 value is 0.588 or $58.8 \%$. This result shows that all green product variables (X1), green promotion (X2), green packaging (X3) contribute to consumer buying interest "Savana Project" of $58.8 \%$ while the remaining $41.2 \%$ is influenced by other variables outside of the independent this research. Green promotion variables have a dominant influence on customer loyalty with a regression coefficient of 0.501 greater than the other two variables. This shows that green promotion greatly influences consumer buying interest Based on Test $\mathrm{F}$ the results of the analysis show that green products, green promotion, green packaging simultaneously have a significant effect on buying interest, and can contribute to the purchase interest variable of $57.9 \%$.

Based on the T-Test analysis shows that green products, green promotion, green packaging partially have a positive effect on buying interest. The green product does not have a significant effect on consumer interest in Savana Project. While the other two variables, green promotion, and green packaging have a significant influence on consumer purchasing interest of Savana Project.

\section{REFERENCES}

Al-Bakri Thamer Yasser and Al - Nouri, Ahmad Nizar. (2007). Green Marketing. AlYazuri Scientific For Publishing and Distribution.

Assael, H. 2002. Consumer Behavior and Marketing Action. Fourth Edition. Boston: PWS-Kent Publishing Company

Dahlstorm, Robert. (2010). Green Marketing Management. United States of America: South - Western Cengage Learning

Durif, F., Caroline B, and Charles J. (2010). In Search of a Green Product Definition. Innovative Marketing. Volume 6, issue

Fatur Rahman, Pamasang S. Siburian, Gusti Noorlitaria A. 2017. Pengaruh Green Marketing Mix terhadap Keputusan Pembelian Konsumen Produk Tupperware di Samarinda. Jurnal Forum Ekonomi .19(1).

Friska Lovia M Panjaitan. Pengaruh Green Marketing Terhadap Minat Beli Konsumen ( Studi : Cluster Whelford di Bumi Serpong Damai). Universitas Indonesia 2014 
Grant, John. (2007). The Green Marketing Manifesto. John Wiley \& Sons, Ltd., West Sussex, England. Journal of Business Ethics, Vol. 29.

Haryadi, R., (2009). "Pengaruh Strategi Green Marketing Terhadap Pilihan KonsumenMelalui Pendekatan Marketing Mix Studi Kasus pada The Body Shop Jakarta", Tesis S2, Universitas Diponegoro, Semarang.

Hashem, Tareq N dan Nahla A. AlRifai. (2011), "The influence of applying Green Marketing mix by chemical industries companies in three Arab States in West Asia on consumer's mental image", Jordania, Henion K., Kinnear Th., 1976, ecological Marketing, Columbus, Ohio, American Marketing Association, pp. 248-312

Honorata Ratnawati Dwi Putranti, dan Suparmi. Pengaruh Kemasan Ramah Lingkungan Dan Informasi Terhadap Minat Beli Ulang (Studi Konsumen Amdk Kota Semarang). UNTAG Semarang 2016.

Imam Santoso1 dan Rengganis Fitriyani. Green Packaging, Green Product, Green Advertising, Persepsi, Dan Minat Beli Konsumen.. Universitas Brawijaya Malang 2016.

Kennedy, E. J. 2009. Era Bisnis Ramah Lingkungan. Jakarta Barat: PT Bhuana Ilmu Populer.

Kotler, Philip. Keller. 2006. Manajemen Pemasaran. Jilid Dua. Edisi Kesepuluh. Alih Bahasa Benyamin Molan. Jakarta : Indeks

Kotler dan Keller. 2009. Manajemen Pemasaran. Jilid I. Edisi ke 13. Jakarta: Erlangga.

Kotler, dan Keller. (2012). Manajemen Pemasaran. Edisi 12. Jakarta: Erlangga.
Malhotra, Naresh K. 2005. Riset Pemasaran Pendekatan Terapan Ed. 4 Jilid 1. Jakarta : Indeks.

Mahbub Alfa Roby dan Anik Lestari Andjarwati. 2014. Pengaruh Green Product Pada Minyak Goreng Ecoplanet Terhadap Minat Beli Konsumen. Jurnal Ilmu Manajemen. 4(2).

Mathur, L.K. Mathur, I. 2000.An Analysis of the Wealth Effect of Green Marketing Strategies, Journal of Business Research, 50(2), 193-200.

Mintu, A. T. \& H. R. Lozada. 1993. Green Marketing Education: A Call For Action, Marketing Education Review, 3 (Fall): 17-23

Muhamad Tunjung Puspito. Pengaruh Green product Pertamax Terhadap Minat Beli Konsumen (Studi PT. Pertamina Bandung 2016). Universitas Telkom 2016.

Nugrahadi, Eko Wahyudi. 2002. "Pertanian Organik Sebagai Alternatif Teknologi dalam Upaya Menghasilkan Produk Hijau”. Makalah Falsafah Sains (PPs 702) Program Pasca Sarjana IPB. http://www.deptan.go.id

Situmorang, James R. 2011. Pemasaran Hijau yang Semakin Menjadi Kebutuhan dalam Dunia Bisnis. Jurnal Administrasi Bisnis. FISIPUnpar, 2(7): 131-142

Schiffman dan Kanuk. 2007. Perilaku Konsumen. Edisi Kedua. Jakarta: PT. Indeks Gramedia

Sugiyono. 2008. Metode Penelitian Bisnis. Alfabeta. Jakarta.

Sugiyono. 2013. Metode Penelitian Bisnis. Bandung: Penerbit Alfabeta.

Vivin Lestari. Analisa Peran Prilaku Konsumen Untuk Merespon Green Marketing ( Survei Pada Konsumen 
JSM, Volume 1, Number 2, July 2019

P-ISSN : 2655-3651

E-ISSN : 2656-0435

Air Mineral Merel Ades Dikalangan Mahasiswa Ma'had Puteri Sunan Ampel Al - Ali Universitas Islam Negeri Maulana Malik Ibrahim Malang ). UIN Malang 2013
Zhu, Bing. 2013. The Impact of Green Advertising on Customers Purchases Intention Of Green Products. World Review Of Bussiness Research. 3(3), pp:72-80 